P. Ravussin MD, D.P. Archer MD, E. Meyer PH D, M. Abou-Madi MD, L. Yamamoto MD, D. Trop MD

\title{
The effects of rapid infusions of saline and mannitol on cerebral blood volume and intracranial pressure in dogs
}

The role of osmotic brain dehydration in the early reduction of intracranial pressure (ICP) following mannitol administration has recently been questioned and a decrease in cerebral blood volume ( $C B V$ ) proposed as the mechanism of action. To evaluate this hypothesis, relative $C B V$ changes before and afier mannitol infusion were determined by collimated gamma counting across the biparietal diameter of the exposed skull in six dogs. Red blood cells were labelled with chromium-51. Cerebral blood volume (CBV), total blood volume (TBV), ICP, mean arterial pressure (MAP), central venous pressure $(C V P)$, haematocrit and osmolality were serially measured after infusions of $10 \mathrm{ml} \cdot \mathrm{kg}^{-1}$ of normal saline (control study) and of 20 per cent mannitol (mannitol study). The solutions were administered over a twominute period; a 30-minute equilibration period intervened between the saline and mannitol infusions.

We demonstrated that the mannitol infusion was associated with significant increases in relative $C B V(25$ per cent), ICP $(7 \mathrm{mmHg}), \mathrm{CVP}\left(11 \mathrm{~cm} \mathrm{H}_{2} \mathrm{O}\right)$, and $\mathrm{TBV}$

\section{Key words}

FLUID BALANCE; mannitol; BRAIN: intracranial pressure, oedema, cerebral blood volume.

From the Department of Neuroanaesthesia and the Cone Laboratory for Neurosurgical Research, Montreal Neurological Institute and Hospital, McGill University, Montreal, Quebec

Address correspondence to: D.P. Archer, M.D., Department of Neuroanaesthesia, Montreal Neurological Institute and Hospital, 3801 University Street, Montreal, Quebec, Canada, H3A 2B4
(50 per cent). MAP declined significantly (14 per cent) after mannitol infusion. The administration of saline, although associated with an increase in TBV (18 per cent), was not associated with any significant change in $C B V, I C P, M A P$ or $C V P$.

The increase in relative $C B V$ persisted for 15 minutes after mannitol infusion, while the ICP returned to control within five minutes and continued to decrease. This study supports the fact that after rapid mannitol infusion, ICP begins to decrease only once the dehydrating effect has counteracted the increase in brain bulk caused by the increase in cerebral blood volume.

Rapid infusion of mannitol has been shown to be associated with a transient rise in intracranial pressure (ICP). ${ }^{1,2}$ The mechanism for this change has been postulated to be an increase in cerebral blood volume (CBV) secondary to the rapid increase in total blood volume caused by mannitol. Mannitol has also been shown to vasodilate cerebral and systemic vasculature, ${ }^{3.4}$ and to release histamine from basophils by non-immunologic mechanisms. $^{5}$

Recently Muizelaar et al. ${ }^{6}$ observed that pial arteriolar diameter decreased after rapid administration of mannitol in cats and suggested a viscosityCBF autoregulation mechanism. They postulated that since vasoconstriction might result in decreased CBV, the early decrease in ICP seen after mannitol administration was due to a decrease in CBV and not to osmotic dehydration of the brain as had been previously established for hyperosmolar agents. ${ }^{7-10}$

Thus, the literature is contradictory concerning the advisability of rapid administration of mannitol 
to patients with intracranial hypertension. One group of investigators proposed that rapid administration (by abruptly decreasing blood viscosity) may contribute to early reduction of ICP. Another body of evidence suggests that rapid mannitol administration may be detrimental to cerebral perfusion by increasing ICP and CVP, while decreasing arterial pressure. Faced with this conflicting information, we initiated studies in dogs to directly measure CBV and ICP after the rapid administration of mannitol.

\section{Methods}

Six unmedicated mongrel dogs (weights $17-24 \mathrm{~kg}$ ) were studied. The experimental protocol was approved by the Montreal Neurological Institute Facility Animal Care Committee.

\section{General procedure}

Anaesthesia was induced intravenously with pentobarbitone $30 \mathrm{mg} \cdot \mathrm{kg}^{-1}$ and morphine $0.3 \mathrm{mg} \cdot \mathrm{kg}^{-1}$, and muscle relaxation obtained with pancuronium $0.1 \mathrm{mg} \cdot \mathrm{kg}^{-1}$ IV. Following oral endotracheal intubation, controlled ventilation with medical air was provided by a Bird Mark 7 ventilator (Bird Corp, Palm Springs, Calif, USA). Ventilation was adjusted to produce normocarbia and monitored with an infra-red end-tidal $\mathrm{CO}_{2}$ analyzer (Siemens $\mathrm{AG}$, Erlangen, West Germany). Supplemental morphine and pancuronium were given as needed. With the animal in the lateral position, the bladder was catheterized and after infiltration with $5 \mathrm{ml}$ of bupivacaine $(0.125$ per cent), the left femoral vessels were exposed surgically. The femoral artery was cannulated with a 16 gauge catheter for blood sampling and measurement of arterial pressure (strain gauge transducer, Bentley-Trantec Model 800 , Bentley Lab. Inc, Irvine, Calif, USA). Once the animal was placed in the prone position (see below), the transducer was referenced to the midthoracic line. The femoral vein received two 16 gauge cannulae, one for fluid and drug administration and another which was advanced into the right atrium for the measurement of central venous pressure (CVP). Temperature was monitored by a rectal thermistor probe using a 43 TD TeleThermometer (Yellow Springs Instrument lnc, Yellow Springs, Ohio, USA) and maintained at $38 \pm 1^{\circ} \mathrm{C}$ by heat lamps or ice packs. Heart rate was monitored with ECG leads. Six $\mathrm{mg} \cdot \mathrm{kg}^{-1} \cdot \mathrm{hr}^{-1}$ of normal saline were infused to provide for fluid requirements. With the animal in the prone position the head was fixed in a stereotactic frame $15 \mathrm{~cm}$ above the right atrium. After infiltration of the area with $20 \mathrm{ml}$ of 0.125 per cent bupivacaine, a midline scalp incision was made and the muscles reflected laterally from the posterior margins of the orbit to the occipital crest in order to minimize radioactive emissions from extracerebral cranial tissues. Cerebrospinal fluid pressure (CSFP) was measured through a 20 gauge cannula inserted into the cisterna magna and connected to a strain gauge transducer referenced to the external auditory meatus. Mean CSFP and mean arterial pressure (MAP) were determined by electronic integration of the respective transducer signals using a Siemens Sirecust 300 System (Siemens AG, Erlangen, West Germany). Arterial blood gases were serially measured during the procedure, using a Corning 165/2 $\mathrm{pH} / \mathrm{blood}$ gas analyzer (Corning Medical, Boston, Mass, USA). $\mathrm{PaCO}_{2}$ was maintained at $39 \pm 2$ $\mathrm{mmHg}$ and $\mathrm{PaO}_{2}$ was found constantly higher than $85 \mathrm{mmHg}$.

\section{Measurement of $T B V$ and relative $C B V$}

Using the method of Risberg et al., " modified only by using Cr-51 instead of RISA, relative cerebral blood volume (CBV) was determined by external gamma counting of red blood cells labelled with 4-5 mCi of chromium-51 $1^{12}$ (Merck Frosst Canada Inc, Montreal). Following 60 minutes of exposure to chromium-51, the red cells were washed twice; plasma activity after injection and equilibration was less than 0.9 per cent. Following injection of the labelled cells, barbotage with blood was used to rinse the syringe. Twenty minutes were allowed for the labelled red cells to equilibrate in the blood pool. A sensitive bismuth germanate (BGO) scintillation detector ${ }^{13}$ ( $35 \mathrm{~mm}$ thick, $18 \mathrm{~mm} \times 32 \mathrm{~mm}$ ) (Harshaw Chemical Co, Solon, Ohio, USA) coupled to a photomultiplier tube (type R1213 Hamamatsu TV Co Ltd, Hamamatsu City, Japan) was focused horizontally across the biparietal diameter of the exposed skull at a distance of $8-10 \mathrm{~cm}$. The detector had a narrow lead collimator $(20 \mathrm{~mm}$ diameter aperture, $50 \mathrm{~mm}$ long) extending from the detector face to within $3-4 \mathrm{~cm}$ of the skull surface and was surrounded by at least $3 \mathrm{~cm}$ thickness of lead shielding. The impulses from the detector passed through a preamplifier into a single channel 


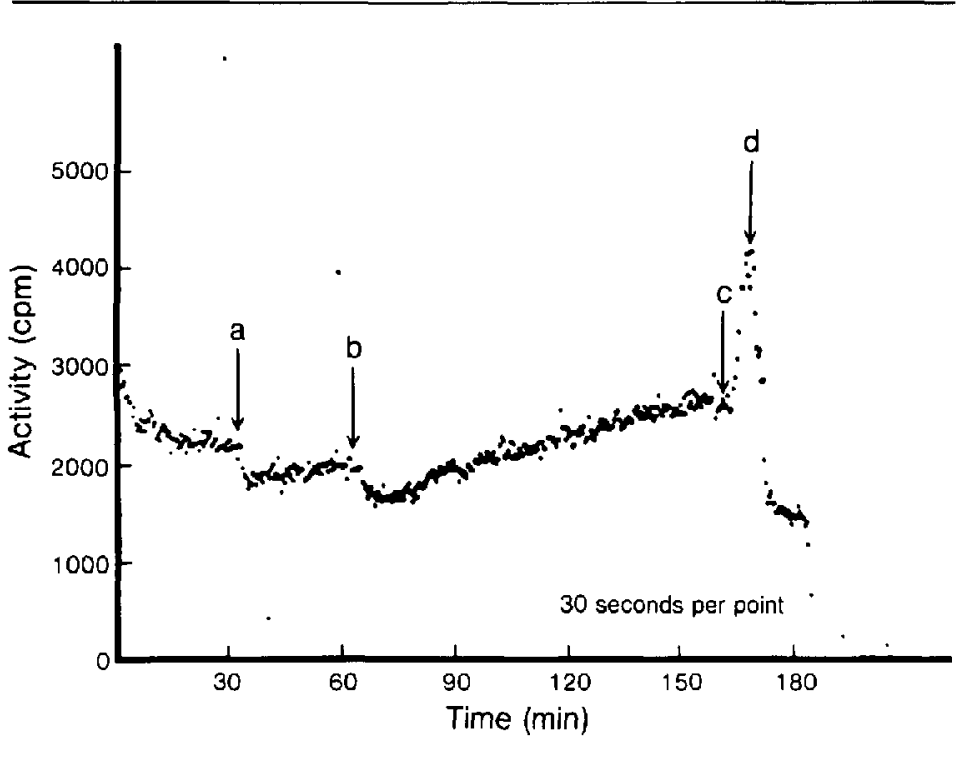

FIGURE 1 Recording of external gamma counts (HC) during one entire experiment, starting just after injection of Cr-51-labelled red blood cells. See text for details.

analyzer with a "window" set at 195 to $450 \mathrm{keV}$ (Cr-51 photopeak: $320 \mathrm{keV}$ ). This energy-selective counting rejected scattered radiation and restricted the visual field of the detector. The output from the single channel analyzer was fed into a timer-scaler and printer (Model 2089 Serial Scanner Printer, Camberra Industries Inc, Meridien, Connecticut, USA). External gamma counting (head counts, HC) was registered over one minute intervals, except for sample points during the first two minutes after mannitol infusion when 30 second intervals were used. The background level for the detector before radioisotope administration was about 300 counts per minute (cpm); count rates during the experiment were typically 3000 to $4000 \mathrm{cpm}$. The contribution to $\mathrm{HC}$ from extracranial sources was evaluated by comparing the count rates before and after surgical removal of the brain. For this determination the animal was killed with potassium chloride and the major neck vessels rapidly ligated before removal of the brain through a large craniectomy. Extracranial contribution was evaluated to be 30 per cent, a figure which agrees with results from a previous report of this method. ${ }^{11,14}$ Since the effect of the experiment on contribution from extracranial sources was unknown, no correction for this contribution was applied. The sensitivity of the method to changes in cerebral blood volume was verified in each animal by inducing hypercarbia $\left(\mathrm{PaCO}_{2}\right.$ $50 \pm 2 \mathrm{mmHg}$ ). A rise in gamma count rates was observed in each experiment (one representative experiment in Figure 1). Total gamma emission from peripheral arterial samples (cpm/g blood, BC) was assayed in a well counter (Model $810 \mathrm{c}$, Baird Atomic Inc, Cambridge, Mass, USA). Simultaneous arterial and central venous samples agreed within 3 per cent, indicating that the degree of haemodilution brought about by mannitol was similar in the central and peripheral vascular beds. Average arterial gamma count rates exceeded $100,000 \mathrm{cpm} / \mathrm{g}$. Relative CBV at a given time, $t$, was calculated as the ratio of head counts over peripheral counts at that time, normalized to the baseline ratio ( $b=$ head counts/peripheral counts prior to saline and mannitol respectively), and expressed as a percentage.

(1) $\begin{aligned} & \text { Relative } \mathrm{CBV} \\ & \text { (\% of baseline) }\end{aligned}=\frac{\mathrm{HC}(\mathrm{t}) / \mathrm{BC}(\mathrm{t})}{\mathrm{b}} \times 100$

It was assumed that the small cerebral yessel/large 
vessel haematocrit ratio was constant throughout the experiment.

The absolute total blood volume, TBV, was calculated by the dilution equation: ${ }^{15}$

(2) $\mathrm{TBV}(\mathrm{ml})=\mathrm{A} /(\mathrm{BC} \times \mathrm{d})$

where $\mathrm{A}$ represents the total amount of injected $\mathrm{Cr}$ $51(\mathrm{cpm}), \mathrm{BC}$ the peripheral blood $\mathrm{Cr}-51$ activity $(\mathrm{cpm} / \mathrm{g})$, and $\mathrm{d}$ the blood density $(1.05 \mathrm{gm} / \mathrm{ml}){ }^{15}$ Contamination of $\mathrm{Cr}-51$ in the plasma fraction was less than $0.9 \%$ and total urinary activity was less than 0.9 per cent of the total injected activity.

\section{Protocol for saline and mannitol infusions}

The effects of the rapid addition of a large volume of fluid to the circulation were observed by giving each animal $10 \mathrm{ml} \cdot \mathrm{kg}^{-1}$ of normal saline prior to the rapid infusion of the same quantity of mannitol. The sampling and measurement protocol was the same for the saline infusion as for mannitol (see below). To allow equilibration of the saline between intravascular and extravascular compartments, thirty minutes were allowed to elapse between the saline and the start of the mannitol infusion. Rapid infusion of a $2 \mathrm{~g} \cdot \mathrm{kg}^{-1}$ dose of 20 per cent mannitol has been shown to be associated with an increase in ICP. ${ }^{1}$ One of the six dogs receiving saline did not receive mannitol because of a disconnection of the intravenous line.

Before both infusions, baseline measurements were made of MAP, CBV, CVP, CSFP, and urine output. Blood samples were drawn for $\mathrm{BC}$, haematocrit (Hct), and osmolality (Osm). The fluids (10 $\mathrm{ml} \cdot \mathrm{kg}^{-1}$ of normal saline or 20 per cent mannitol) were infused over a two-minute period with "Time 0" set at 1 minute after the start of the infusion. Serial measurements and blood sampling were performed $\frac{1}{2}, 1,2,3,5,8,15$, and 30 minutes after "Time 0". Additional sampling and measurements were performed 45,60 , and 90 minutes after mannitol infusion but not after saline. Osmolality was measured by freezing point depression using an Osmette-A osmometer (Precision System Inc, Sudbury, Mass, USA). Haematocrit was measured by direct reading, using a Readacrit centrifuge (Clay Adams, Parsippany, New Jersey, USA). Baseline and post-infusion data were compared using paired t-tests with the Bonferroni method for multiple comparisons. ${ }^{16}$ Values of $t$ which yielded $p<0.05$ were considered statistically significant.

\section{Results}

A representative recording of activity (external gamma counts, $\mathrm{HC}$ ) during one entire experiment is shown in Figure 1. Activity declines at the beginning of the first 20 minutes of the experiment, after the injection of the Cr-51-labelled red blood cells until at point a, the saline bolus is given. During the 30 minutes of the saline (control) experiment, equilibration occurs and activity returns to presaline levels. At this point, b, the mannitol bolus is given. The activity follows a pattern similar to that seen with saline, and count rates fall because of haemodilution. After point $c$, the animal was rendered hypercarbic, and then at point $d$, hyperventilated. At this point in the experiment, haematocrit was relatively stable and the rise and fall in activity confirmed the dilatatory and constrictive effects of hypercarbia and hypocarbia respectively on the cerebral vasculature.

CBV and TBV were calculated according to equations 1 and 2 . The results, along with the other measured parameters, are summarized in Tables I and II and Figures 2, 3 and 4. Both the absolute value of baseline TBV ( 6.9 per cent \pm 0.7 per cent of body weight) and its increase after mannitol ( 50 per cent) are in agreement with previous studies. ${ }^{17,18}$

The effects of the bolus of normal saline are shown in Figure 2. The rapid changes in TBV and Hct reflect the haemodilution by the saline infusion. These changes are in marked contrast to the stability of the CBV, CVP, and CSFP. At thirty minutes after the infusion of saline, the TBV is still increased 4 per cent above control, confirming that approximately one-third of the infused saline remained within the vascular tree after equilibration. Mean urine output for the entire procedure was 550 $\pm 25 \mathrm{ml}$.

The mannitol infusion produced more marked changes in Het and TBV (Figure 3), and was accompanied by increases in CBV and CSFP (Figure 4 ). These changes were maximal by two minutes. The subsequent fall in CSFP preceded the onset of duresis in each animal. Despite a significant rise in CVP, MAP fell significantly by 14 per cent, an effect not seen with saline infusion. The change in osmolality was both large (44 mosmol $\cdot \mathrm{kg}^{-1}$ ) and rapid (maximal by two minutes); intravenous injection of Evan's blue dye before mannitol infusion ( $10 \mathrm{ml}$ of a 0.5 per cent solution) 
TABLE I Summary of data: Control saline study (Mean \pm S.D.)

\begin{tabular}{|c|c|c|c|c|c|c|c|c|c|}
\hline & \multirow[b]{2}{*}{ Baseline } & \multicolumn{8}{|c|}{ Time in minutes } \\
\hline & & $\frac{t}{t}$ & $I$ & 2 & 3 & 5 & 8 & 15 & 30 \\
\hline \multirow{2}{*}{$\begin{array}{l}\mathrm{CBV}, \% \text { of control } \\
\pm \mathrm{SD}\end{array}$} & 100 & 100 & 98 & 98 & 100 & 99 & 98 & 98 & 98 \\
\hline & 0 & 3 & 4 & 4 & 4 & 3 & 2 & 4 & 3 \\
\hline \multirow{2}{*}{$\begin{array}{l}\text { TBV }, \% \text { of control } \\
\pm \mathrm{SD}\end{array}$} & 100 & $117^{*}$ & $118^{*}$ & $117^{*}$ & $116^{*}$ & $116^{*}$ & $113^{*}$ & 108 & 104 \\
\hline & 0 & 4 & 4 & 4 & 5 & 6 & 5 & 5 & 4 \\
\hline \multirow{2}{*}{$\begin{array}{l}\mathrm{CSFP}, \mathrm{mmHg} \\
\pm \mathrm{SD}\end{array}$} & 10 & 12 & 11 & 11 & 11 & 11 & 10 & 10 & 10 \\
\hline & 3 & 4 & 4 & 5 & 5 & 5 & 4 & 4 & 4 \\
\hline \multirow{2}{*}{$\begin{array}{l}\text { CVP, } \mathrm{cmH}_{2} \mathrm{O} \\
\pm \mathrm{SD}\end{array}$} & 0 & 2 & 3 & 2 & 1 & 1 & 1 & 0 & 0 \\
\hline & 3 & 4 & 5 & 4 & 3 & 3 & 3 & 3 & 3 \\
\hline \multirow{2}{*}{$\begin{array}{l}\text { MAP, } \% \text { of control } \\
\pm S D\end{array}$} & 100 & 104 & 105 & 105 & 102 & 102 & 101 & 104 & 106 \\
\hline & 0 & 3 & 5 & 7 & 4 & 5 & 7 & 6 & 5 \\
\hline \multirow{2}{*}{$\begin{array}{l}\text { HR, \% of control } \\
\pm \mathrm{SD}\end{array}$} & 100 & 114 & 115 & 113 & 108 & 107 & 103 & 103 & 103 \\
\hline & 0 & 9 & 13 & 12 & 11 & 10 & 9 & 10 & 10 \\
\hline \multirow{2}{*}{$\begin{array}{l}\text { Hct, } \% \text { of control } \\
\pm \mathrm{SD}\end{array}$} & 100 & $86^{*}$ & $81^{*}$ & $85^{*}$ & $86^{*}$ & $87^{*}$ & $88^{*}$ & 92 & 99 \\
\hline & 0 & 8 & 5 & 4 & 4 & 6 & 6 & 8 & 5 \\
\hline \multirow{2}{*}{$\begin{array}{l}\text { Hct, vol \% } \\
\pm \mathrm{SD}\end{array}$} & 40 & $35^{*}$ & $33^{*}$ & $34^{*}$ & $34 *$ & $35^{*}$ & $35^{*}$ & 37 & 40 \\
\hline & 5 & 6 & 5 & 5 & 5 & 5 & 5 & 5 & 5 \\
\hline \multirow{2}{*}{$\begin{array}{l}\text { Osm, \% of control } \\
\pm \mathrm{SD}\end{array}$} & 100 & 100 & 100 & 100 & 99 & 99 & 100 & 101 & 100 \\
\hline & 0 & 1 & 1 & 1 & 2 & 3 & 3 & 1 & 1 \\
\hline \multirow{2}{*}{$\begin{array}{l}\text { Osm, mosmol } \cdot \mathrm{kg}^{-1} \\
\pm \mathrm{SD}\end{array}$} & 301 & 302 & 301 & 302 & 300 & 299 & 300 & 304 & 302 \\
\hline & 6 & 5 & 3 & 5 & 9 & 12 & II & 6 & 6 \\
\hline
\end{tabular}

$*_{\mathrm{p}}<0.05 ., \mathrm{n}=6$.

did not result in any observable staining of the brain when examined at the termination of the experiment. This confirms that the blood-brain barrier was not grossly disrupted by the mannitol infusion.

\section{Discussion}

This method for determining relative cerebral blood volume has been described by Risberg et al. " The contamination from extracranial sources in our study was approximately 30 per cent, similar to that obtained by other studies. ${ }^{11,14}$ The changes in $\mathrm{HC}$ observed during hyper- and hypocarbia were appropriate for a method that measured cerebral blood volume. Contamination of the collimated head counter by radiation originating in the large vessels in the neck could be a source of error in this study. In the venous circulation in particular, distension of extracranial vessels due to increases in CVP could artifactually increase the head counts. The experimental set-up with the head $15 \mathrm{~cm}$ above the heart attempted to minimize this factor. Tomographic radiation scanning (PET) would definitely resolve the issue.

The rapid infusion of normal saline $\left(10 \mathrm{mg} \cdot \mathrm{kg}^{-1}\right)$ in normal dogs produced no significant change in cerebral blood volume or intracranial presure. Other authors ${ }^{19}$ have reported an increase in ICP and cerebral blood flow following haemodilution with lactated Ringer's solution. The degree of haemodilution achieved in the present saline study (Hct 33 per cent) was not sufficiently profound to expect a vasodilatory effect on the cerebral vasculature (reported with haematocrits less than 30 per cent). ${ }^{20}$ Todd et al. ${ }^{19}$ produced a minimum haematocrit (mean) of 19 per cent in their study, a level at which cerebral vasodilation would be expected. The effects of the saline infusion on the subsequent mannitol experiments could not be determined from this study. The osmotic effects of mannitol preclude a crossover design. ICP and CBV are not changed by the saline infusion; however, we speculate that expansion of the extracellular space with saline may accentuate the osmotic effects of mannitol. 
TABLE II Summary of data: Mannitol study (Mean \pm S.D.)

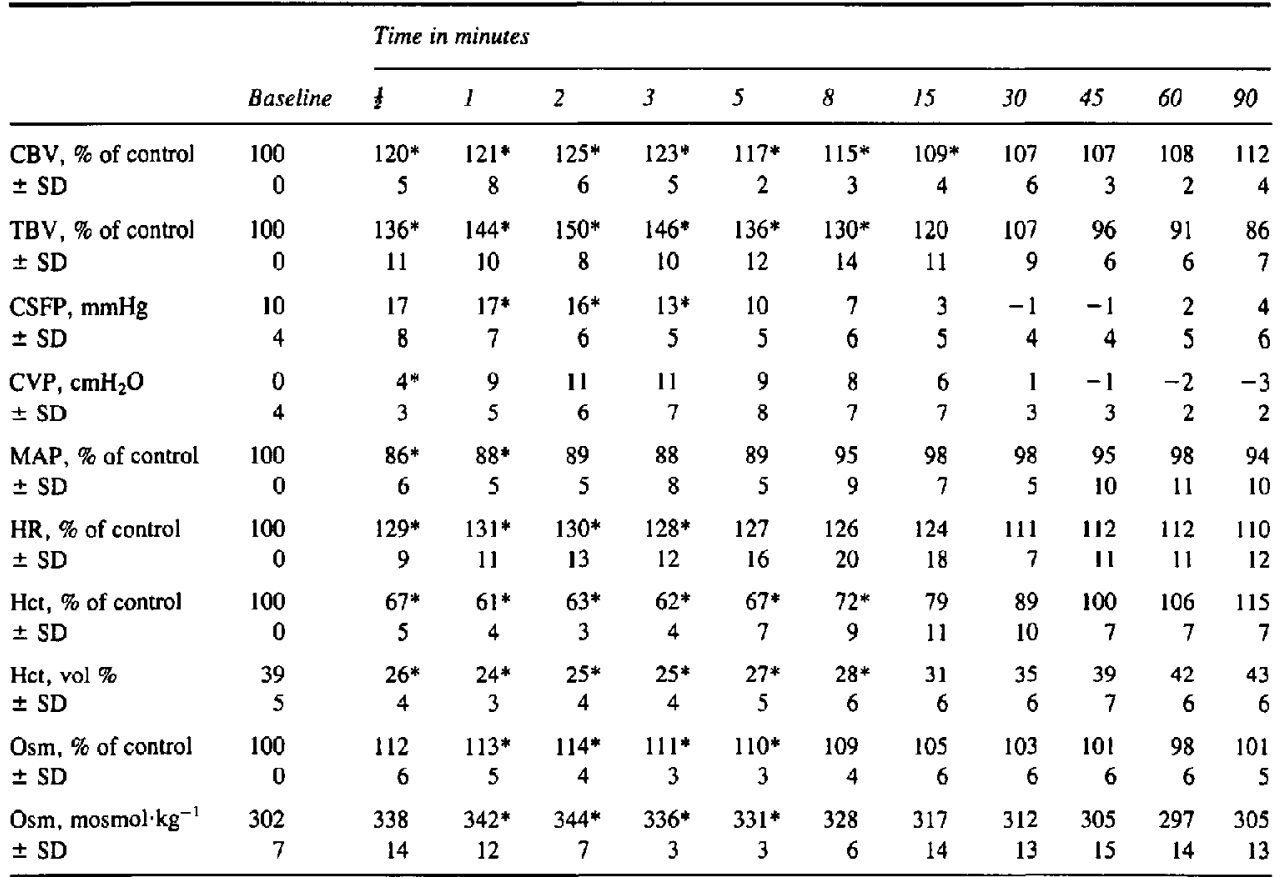

${ }^{*} \mathrm{p}<0.05, \mathrm{n}=5$.

The infusion of mannitol produced a large increase in CBV. This increase was most marked two minutes after infusion and CBV remained significantly elevated for fifteen minutes.

Factors that could have contributed to the increase in CBV include an increase in cerebral venous pressure resulting from an increased CVP, ${ }^{21}$ vasodilation due to haemodilution, ${ }^{20,22}$ autoregulation-mediated vasodilation in response to a fall in MAP, ${ }^{23}$ and direct vasodilation of the cerebral vasculature by mannitol. ${ }^{3.24}$ The experimental setup, with the head $15 \mathrm{~cm}$ above the right atrium, eliminated the possibility that the CVP changes (maximum $11 \mathrm{~cm} \mathrm{H}_{2} \mathrm{O}$ ) contributed significantly to the increase in CBV. Haemodilution, if it acutely reduces the haematocrit to less than 30 per cent, ${ }^{20}$ has been shown to be associated with increases in cerebral blood flow; the cerebral vasculature dilates to preserve oxygen delivery. In this respect the saline and mannitol portions of the study differed, because with mannitol the haematocrit fell to a level (24 per cent) at which vasodilation from haemodilution would be anticipated, whereas during the saline study it did not ( 33 per cent).

The decrease in MAP following rapid infusion of mannitol has been observed previously with mannitol, ${ }^{4}$ hypertonic glucose ${ }^{25}$ and radiographic contrast medium. ${ }^{26}$ Findlay et al. ${ }^{5}$ demonstrated that hyperosmolar solutions, including mannitol, cause release of histamine from human basophils by a nonimmunologic mechanism and do so in clinically relevant concentrations. In a study in cats given $1 \mathrm{~g} \cdot \mathrm{kg}^{-1}$ of 25 per cent mannitol over one minute, Muizelaar et al. ${ }^{6}$ did not observe any fall in MAP, suggesting that there may be species differences in histamine liberation by mannitol. In addition to histamine release, mannitol has been shown to be a direct vasodilator in human skeletal muscle ${ }^{27}$ and in cerebral vasculature. ${ }^{3,24}$ Finally, vascular resistance has been shown to decrease with mannitol infusion due to a fall in blood viscosity. ${ }^{28,29}$ Although the decrease in MAP observed could have contributed to the increase in CBV, the changes in MAP appear to return to normal before CBV does 


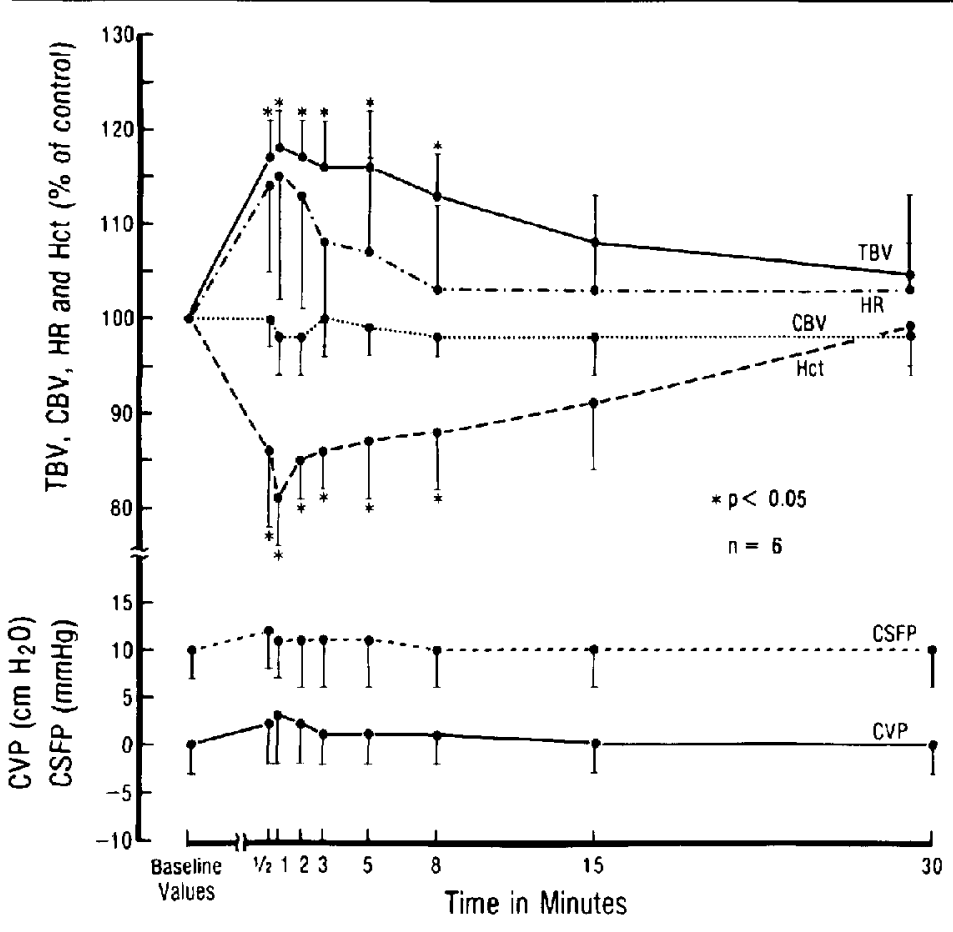

FIGURE 2 TBV, CBV, HR, and Hct (\% of control \pm S.D.), CVP (meań value, $\mathrm{cm} \mathrm{H}_{2} \mathrm{O} \pm$ S.D.), and CSFP (mean value, $\mathrm{mmHg} \pm$ S.D.) after a rapid infusion of normal saline $\left(10 \mathrm{ml} \cdot \mathrm{kg}^{-1}\right.$ ).

(see Figures 3 and 4) suggesting that other factors (in particular haemodilution, see above) are operative. Further studies, taking steps to hold MAP constant could directly address the contribution of hypotension to the changes in $\mathrm{CBV}$.

The parameter which appears to integrate the effects of CBV and osmotic dehydration is the CSFP. After saline infusion no significant increase in CBV took place and CSFP did not rise. In the case of mannitol, however, CSFP rose sharply, but then declined more rapidly than the $\mathrm{CBV}$, returning to control levels (and continuing to decrease) at a time when CBV was still increased. This suggests that osmotic dehydration was able to counterbalance quickly the space-occupying effect of the increase in CBV. ${ }^{30,31}$

\section{Conclusions}

Rapid infusion of mannitol produced an increase in cerebral blood volume which was associated with an increase in CSF pressure. Central venous pressure was not a contributing factor in the changes of CBV or CSFP. The increases in CBV and especially in CSFP were transient, the latter probably limited by the rapid dehydrating effect of mannitol.

Rapid infusion of saline, though it produced a significant increase in total blood volume, was not associated with any significant increase in $\mathrm{CBV}$ or CSFP.

Thus, the beneficial effects of mannitol in reducing brain bulk were preceded in this model by increases in cerebral blood volume and intracranial pressure. Although rapid mannitol administration may be associated with decreases in pial arteriolar diameter as observed by Muizelaar et al., ${ }^{6}$ that effect does not appear to represent the acute effect of mannitol on total or regional CBV. Although these results cannot be transferred to conditions of intracranial hypertension, they suggest that the clinical practice of administering titrated doses of 




FIGURE 3 TBV, MAP, and $\mathrm{Hct}$ (\% of control \pm S.D.) and $\mathrm{CVP}$ (mean value, $\mathrm{cm} \mathrm{H}_{2} \mathrm{O} \pm$ S.D.) after a rapid infusion of $20 \%$ mannitol $\left(10 \mathrm{ml} \cdot \mathrm{kg}^{-1}\right)$.

mannitol slowly with a preceding dose of a loop diuretic in patients with severe intracranial hypertension is advisable.

\section{Acknowledgements}

We are grateful to Dr. H. Pappius for her advice and support during this study, and we greatly appreciated technical assistance from the staff members of the Neuroanaesthesia Laboratory, the Cone Laboratory for Neurosurgical Research, and the Neuroisotope Laboratory.

The authors thank C. Elliot, K. McKinnon, and D. Arruda for their help in preparing this manuscript, Dr. Victoria Lees for her editorial assistance, and Charles Hodge for his photographic work.

\section{References}

1 Abou-Madi MN, Trop D, Villemure JG. Effect of changing $\mathrm{PaCO}_{2}$ on intracranial pressure response to bolus infusion of mannitol in dogs. Anesthesiology 1983; 59: A 391.

2 Cottrell JE, Robustelli A, Post K, Turndorf $H$. Furosemide - and mannitol - induced changes in intracranial pressure and serum osmolality and clectrolytes. Anesthesiology 1977; 47: 28-30.

3 Hardebo JE, Nilsson B. Haemodynamic changes in brain caused by local infusion of hyperosmolar solutions, in particular relation to blood-brain barrier opening. Brain Res 1980; 181: 49-59.

4 Coté CJ, Greenhow DE, Marshall BE. The hypotensive response to rapid intravenous administration of hypertonic solutions in man and in the rabbit. Anesthesiology 1979; 50: 30-5.

5 Findlay SR, Dvorak AM, Kagey-Sobotka A, Lichtenstein $L M$. Hyperosmolar triggering of histamine release from human basophils. J Clin Invest 1981 ; 67: 1604-13. 


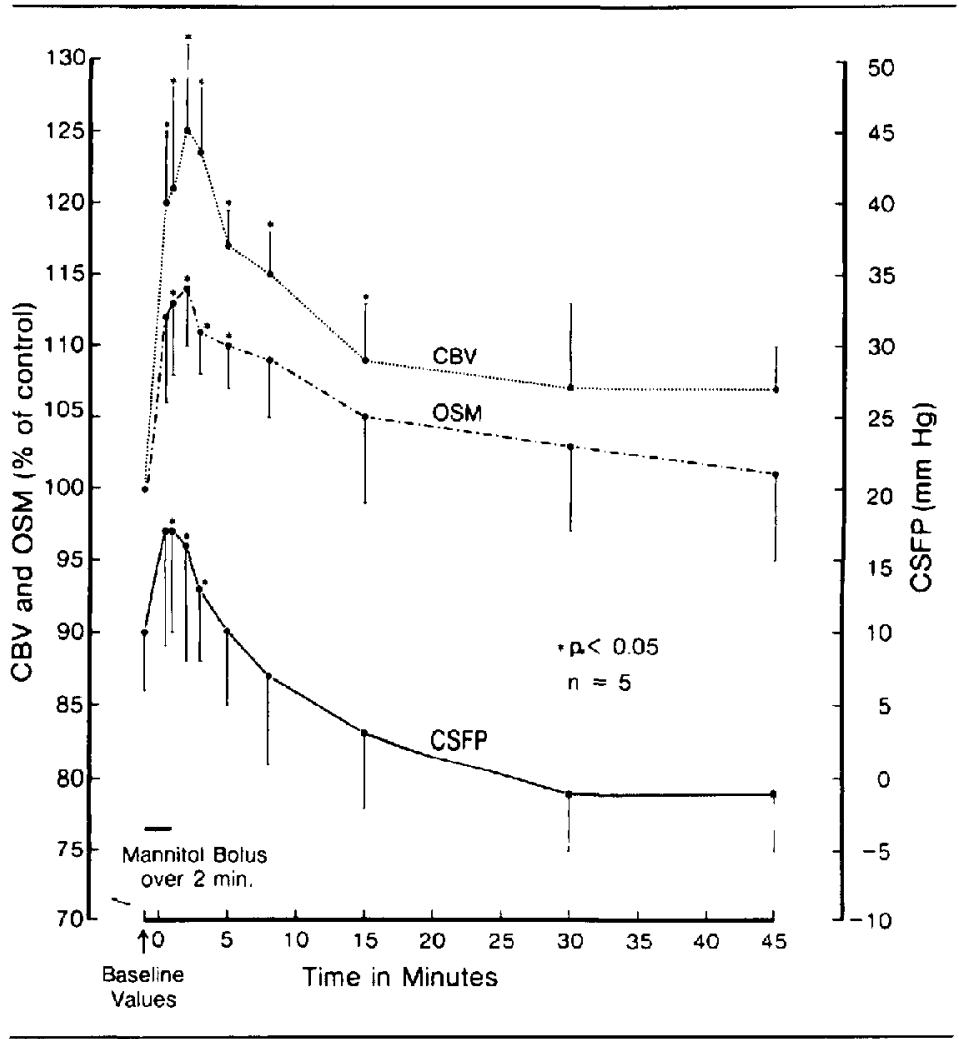

FIGURE 4 CBV and osmolality (\% of control \pm S.D.) and CSFP (mean value, $m m H g \pm$ S.D.) after a rapid infusion of $20 \%$ mannitol $\left(10 \mathrm{ml} \cdot \mathrm{kg}^{-1}\right)$.

\section{Muizelaar JP, Wei EP, Kontos HA, Becker} $D P$. Mannitol causes compensatory cerebral vasoconstriction and vasodilation in response to blood viscosity changes. J Neurosurg 1983; 59: 822-8.

7 Pappius HM, Dayes LA. Hypertonic urea. Its effect on the distribution of water and electrolytes in normal and edematous brain tissues. Arch Neurol $1965 ; 13: 395-402$.

8 Guisado R, Arieff AI, Massry SG. Effects of glycerol administration on experimental brain edema. Neurology 1976; 26: 69-75.

9 Albright $A L$, Latchaw $R E$, Robinson AG. Intracranial and systemic effects of osmotic and oncotic therapy in experimental cerebral edema. J Neurosurg 1984; 60: 481-9.

10 Clasen RA, Cooke PM, Pandolfi S, Carnecki G, Bryar $G$. Hypertonic urea in experimental cerebral edema. Arch Neurol 1965; 12: 424-34.

11 Risberg $J$, Ancri D, Ingvar DH. Correlation between cerebral blood volume and cerebral blood flow in the cat. Exp Brain Res 1969; 8: 321-6.

12 Kirchner PT, ed. Nuclear Medicine Review Syllabus. The Society of Nuclear Medicine Inc, 1980; 388-9.

13 Cho ZH. Farukhi MR. Bismuth germanate as a potential scintillation detector in positron cameras. J Nucl Med 1977; 18: 840-4.

14 Artru AA. Relationship between cerebral blood volume and CSF pressure during anesthesia with isoflurane or fentanyl in dogs. Anesthesiology 1984; 60: $575-9$.

15 Blahd WH, ed. Nuclear Medicine. 2nd ed. New York: McGraw-Hill, 1971: 593-4.

16 Wallenstein S, Zucker CL. Fleiss JL. Some statistical methods useful in circulation research. Circ Res 1980; 47: 1-9.

17 Wood JH, Snyder LL. Simeone FA. Failure of intravascular volume expansion without hemodilution to elevate cortical blood flow in region of experimental focal ischemia. J Neurosurg 1982; 56: 80-91. 
18 Rudehill A, Lagerkranser $M$, Lindquist $C$, Gordon $E$. Effects of mannitol on blood volume and central hemodynamics in patients undergoing cerebral aneurysm surgery. Anesth Analg 1983; 62: 875-80.

19 Todd MM, Tommasino C, Moore S, Drummond $J C$. The effects of acute isovolemic hemodilution on the brain: a comparison of crystalloid and colloid solutions. Anesthesiology 1984; 61: A122.

20 Häggendal E, Nilsson NJ, Norbäck B. Effect of blood corpuscle concentration on cerebral blood flow. Acta Chir Scand (Suppl) 1966; 364: 3-12.

21 Doblar DD, Santiago TV, Kahn AU, Edelman $N H$. The effect of positive end-expiratory pressure ventilation (PEEP) on cerebral blood flow and cerebrospinal fluid pressure in goats. Anesthesiology 1981; 55: 244-50.

22 Borgström L, Johannsson $H$, Siejö $B K$. The influence of acute normovolemic anemia on cerebral blood flow and oxygen consumption of anesthetized rats. Acta Physiol Scand 1975; 93: 505-14.

23 Grubb RL Jr, Phelps ME, Raichle ME, TerPogossian MM. The effect of arterial blood pressure on the regional cerebral blood volume by $x$-ray fluorescence. Stroke 1973; 4: 390-9.

24 Wahl M, Kuschinschy W, Bosse O, Thurau K. Dependency of pial arterial and arteriolar diameter on perivascular osmolarity in the cat. A microapplication study. Circ Res 1973; 32: 162-9.

25 Czary D, Prichard P, Lewis S, Fennesy M. 50\% dextrose-induced anaphylactic syndrome. In: Proceedings of the Tenth International Congress of Allergology, Jerusalem, 1979; 62.

26 Cogen FC, Norman ME, Dunsky E, Hirshfield $J$ Zweiman $B$. Histamine release and complement changes following injection of contrast media in humans. J Allergy Clin Immunol 1979; 54 : 299-303.

27 Lundvall J, Mellander S, White T. Hyperosmolality and vasodilatation in human skeletal muscle. Acta Physiol Scand 1969; 77: 224-33.

28 Burke AM, Quest DO, Chien S, Cerri C. The effect of mannitol on blood viscosity. J Neurosurg 1981; 55: 550-3.

29 Kassel NF, Baumann KW, Hitchon PW, Gerk $M K$, Hill TR, Sokoll $M D$. Influence of a continuous high dose infusion of mannitol on cerebral blood flow in normal dogs. Neurosurgery $1981 ; 9$ : 283-6.

30 Goluboff B, Shenkin HA, Haft $H$. The effects of mannitol and urea on cerebral hemodynamics and cerebrospinal fluid pressure. Neurology 1964; 14 : 891-8.
31 Leech P, Miller JD. Intracranial volume-pressure relationships during experimental brain compression in primates. 3. Effect of mannitol and hyperventilation. J Neurol Neurosurg Psychiat 1974; 37 : $1005-11$.

Résumé

La baisse de la pression intracrânienne après une infusion de mannitol est gênéralement attribuée d̀ un effet osmotique de deshydratation cérébrale.

Récemment, une diminution du volume sanguin cérébral a été suggérée comme méchanisme d'action. Afin d'évaluer cette proposition, le volume sanguin cérébral relatif a été mesuré chez six chiens avant et après une infusion de mannitol, au moyen d'un récepteur de rayons gamma très précisement centré sur le diamètre bipariétal. Les glabules rouges ont été marqués préalablement, au moyen de chrome-51. Le volume sanguin cérébral, le volume sanguin total, la pression intracranienne, la pression artérielle moyenne, la pression veincuse centrale, l'hématocrite et l'osmolalité ont été mesurés en série après des infusions de $10 \mathrm{ml} \cdot \mathrm{kg}^{-1}$ de solution physiologique (contrôle) et de $10 \mathrm{ml} \cdot \mathrm{kg}^{-1}$ de mannitol à 20 pour cent. La durée d' infusion a été de deux minutes. Une période de 30 minutes d'équilibration a eu lieu entre les deux infusions. L'infusion de mannitol a été immédiatement suivie d'une augmentation de 25 pour cent du volume sanguin cérébral, de $7 \mathrm{mmHg}$ de la pression intracrânienne, de $11 \mathrm{~cm} \mathrm{H}_{2} \mathrm{O}$ de la pression veineuse centrale et de 50 pour cent du volume sanguin rotal. La pression artérielle moyenne a baissé de manière significative (14 pour cent). Tous ces changements ont atteint leur maximum à la deuxième minute, et se sont graduellement corrigés dans l'heure après l'infusion de. mannitol. L'infusion de solution physiologique, bien qu' associee d̀ une augmentation du volume sanguin total de 18 pour cent, n'a entraîné aucun changement dans le volume sanguin cérébral, la pression intracrânienne, la pression artérielle moyenne ou la pression veineuse centrale. Après l'infusion de mannitol, l'augmentation du volume sanguin cérébral relatif a persisté de manière significative pendant 15 minutes, alors que la pression intracrânienne retrouvait le niveau de contrôle en cinq minutes et continuait dे baisser rapidement.

Cette étude soutient le fait que, après une infusion rapide de mannitol, la pression intracrânienne ne commence à baisser que lorsque l'effet de deshydratation cérébrale a pu s'exercer et contrecarrer l'augmentation du volume cérébral total causée par l'augmentation transitoire du volume sanguin cérébral. 